\title{
ÚJ KUTATÁSI ASPEKTUSOK AZ ÉLETHOSSZIG TARTÓ TANULÁS TERÜLETÉNः EGY NÉMET PANELKUTATÁS TAPASZTALATAI
}

\author{
RICHMAN GABRIELLA
}

ELTE TáTK Interdiszciplináris Társadalomkutatások Doktori Program

Hans-Peter Blossfeld \& Hans-Günther Rossbach (eds): Education as a Lifelong Process. The German National Educational Panel Study (NEPS). (Second Edition.) Wiesbaden, 2019. Springer VS. xi + 383 p. ISBN 978-3-658-23162-0 (eBook)

A Német Szövetségi Oktatási és Kutatási Minisztérium kezdeményezésében és támogatásával kezdődött meg 2009 . ben az ún. Nemzeti Oktatási/Képzési Panel (Nationales Bildungspanel, NEPS) előkészítése. Hans-Peter Blossfeld, aki a kutatási projektet irányította a kezdeti években, és kollégája, Hans-Guenther Rossbach szerkesztésében 2011-ben jelent meg elöször a kutatást bemutató könyv angol nyelven (Education as a Lifelong Process). A könyv a panelkutatás felépítését és módszertanát elemzi, feltérképezi az adatgyüjtés rendszerét és az adathalmaz összetételét, valamint további kutatási irányokra tesz javaslatot. A most bemutatandó második, frissített kiadás az első kiadás óta történt változásokról számol be.

A könyv önálló fejezetekben (4-9. fejezet) mutatja be a panelkutatás elméleti keretét alkotó hat dimenziót és azt a nyolc életútszakaszt, amely a kohorszok kialakításának alapjául szolgált. A további fejezetek (10-17. fejezet) a kohorszok kialakítását befolyásoló módszertani aspektuso- kat elemzik, valamint bemutatják azokat a megfontolásokat és kutatói választásokat, melyek lehetővé tették az eltérő kutatási szakaszokban használt különböző méröeszközök összekapcsolását. Ezen túlmenően külön fejezet (18. fejezet) tekinti át a megszorító adatvédelmi rendelkezések követésével járó feladatok sorát.

A német panelkutatás által képviselt szemlélet, az ún. életút-perspektíva a figyelmet a tanulás folyamatára irányítja, eltávolodva a formális oktatás szerkezeti felépítését követő hagyományos értékelési szempontoktól, mint például a „felnőttoktatásban részt vevők aránya”, az „iskolaelhagyók aránya”, vagy a „képesség- és kompetenciaelvárások". Az oktatás intézményrendszere másodlagos szerepet kap, törekedve a társadalmi struktúrák és az egyén életében jelentkező pszichoszociális hatások és szociokulturális tényezők összekapcsolására. A NEPS célja, hogy e szemléletbe ágyazva gyưjtsön adatokat a német oktatás rendszeréről és folyamatairól, az életút során az egyén tudáskészletében 
bekövetkezett módosulásokról, valamint a kompetenciakészlet formálódásáról kis gyermekkortól késő felnőttkorig.

A kutatás tervezése során mérlegelésre kerültek az élethosszig tartó tanulás fontosságát hangsúlyozó gazdasági szempontok, mint például a képzettség és a jövedelemnövekedés vagy a kompetenciakészletváltozás és a szakmai előmenetel kapcsolata; valamint helyet kaptak társadalmi és szociális szempontok is, mint például az önmegvalósítás érvényesítéséhez kötött jóllét érzet erősödésének feltételei.

A könyv szerkezeti felépítése mutatja, hogy a szerzők által alkalmazott értékelési szempontok köre tág, azonban néhány értékelési szempont részletesebb elemzése teljesebbé tehette volna a módszertani áttekintést. A konceptualizálás két kulcsdefiníciója a "panelkutatás” és az „élethosszig tartó tanulás" NEPS általi interpretációjára vonatkozó részletesebb áttekintés és a kutatói döntési mechanizmus bemutatásának elmaradása hiányérzetet kelthet. $\mathrm{A} z$ ezekre vonatkozó bővebb tájékoztatás további szakmai aspektusok elemzésének adhatott volna teret, és az olvasói élményt is emelte volna. Ezen túlmenően, különösen napjainkban, fontos értékelési szempont, hogy a kialakított módszertani sajátosságok alkalmasak-e nemzetközi szintü összehasonlításra. Végül az élethosszig tartó tanulás helyére, szerepére és értelmezésére vonatkozó, a tudomány és a szakma által képviselt állásfoglalások összegzése, valamint a szociálpolitikai megfontolások áttekintése újabb komparatív aspektusokkal bővíthette volna az értékelést.

A „panelkutatás” definíciójának részletes bemutatása elmaradt, emiatt a NEPS adatbázis felhasználhatóságának korlátai nem egyértelműek. Hagyományosan panelkutatáson olyan kutatási módszert értünk, mely az egyén vagy háztartás szintjén, több időpontban gyüjt adatokat, és azt vizsgálja, hogy társadalmi jelenségek, problémák - mint például materiális depriváció, iskolaelhagyás, mobilitás, felnőttkori tanulás stb. - egy életszakaszra jellemző, átmeneti jelenségként értelmezendőek-e, vagy azok állandósult, az egyén életét végigkísérő adottságok. Amennyiben a NEPS a fenti definíció alapján épül fel, az operacionalizálás során alkalmazott területi lehatárolás, valamint a kauzalitás mérését szolgáló változók területi lehatárolása kérdéseket vet fel, melyekre a könyv e kiadása még nem tér ki. Ugyanis a nemzetközi gazdasági szervezetek által kialakított egységes statisztikai rendszerek (pl. Eurostat, EU-SILK, OECD.Stat) elemzései alapján bizonyos társadalmi trendek eltérő mértékben, de konzisztensen jelentkeznek az Európai Unió tagállamaiban (https://population-europe. eu/discussion-papers). Németország is az EU tagállamai közé tartozik, így az európai társadalmi trendek hatásainak kezelésére vonatkozó kutatói döntésmechanizmus bemutatása további elemzési aspektusok számbavételének adhat teret. $\mathrm{A} z$ európai gazdaság technológiai átalakulása, a migrációs hullámok ismétlődése, azon belül a gazdasági migráció és a társadalmi mobilitás erősödése, valamint a munkavállalás jogszabályi környezetének oldása és a nyugdíjkorhatár emelése mind olyan társadalmi tényezők, melyeket szükséges számba venni nemzeti szintű elemzés során is.

Emellett további mérlegelésre ad okot az a nemzetközi szervezetek által kezdeményezett és támogatott trend, mely a tagállamok statisztikáinak összehangolására törekszik a tudomány és a szakma által elérhető adatbázisok összehasonlíthatósága érdekében. A könyv a fentiek áttekintésére nem tér ki, és nem foglal állást a NEPS integrálhatóságára és nemzetközi szintü felhasználhatóságára vonatkozóan. 
A longitudinális kutatások esetében az integrálhatóság szintje többszörös értéknövelő hatással bír, többek között azért is, mert e kutatások megvalósítása általában az elvárhatónál jelentősen nagyobb humán erőforrás felhasználását igényli, és az operacionalizálás során meghozandó forrásallokációs döntések a kivitelezést nehezíthetik, tehát a tudományos érték mellett a gazdasági megtérülés kiemelten fontos szemponttá válik. A NEPS esetében az integrálhatóság mértékének számbavétele az eddig említett szempontokon túl a kauzális sémák felismerésének javítása miatt is kritikus, hiszen az élethosszig tartó tanulás szerepét vizsgálja az egyén szintjén. A panelkutatásokat érő egyik leggyakoribb kritika (Sturgis-Allum-Brunton-Smith 2009), hogy az adathalmaz nem alkalmas a kauzális viszonyok felismerésére. Az elégtelenség gyakori oka, hogy a válaszadók döntési mechanizmusának körülményeiben bekövetkezett változás nyomon követése nem biztosított. Ugyanis a panelkutatás ideje alatt módosulhat a populáció összetétele, valamint nemzetközi és nemzeti intézkedések hatásai érvényesülhetnek, továbbá pragmatikus elemek torzító hatását is mérlegelni szükséges, mint például az interjúkérdések ismétlődésének hatásai.

$\mathrm{A} z$ „élethosszig tartó tanulás” fogalmának (mint társadalmi jelenség és mint a NEPS-ben használt kulcsdefiníciók egyike) bővebb tárgyalása, valamint gazdasági, társadalmi és politikai szerepének részletesebb áttekintése szintén azon aspektusok közé tartozik, melyek a panelkutatás elörehaladását bemutató következő kiadás előkészítése során szempontként felmerülhet. A nemzetközi szervezetek által elfogadott definíciók itt is lényegesen eltérnek egymástól, és a tudományos közösség álláspontja is megoszlik. Vannak, akik az élethosszig tartó tanulás kizárólagos céljaként a képességek és kompetenciák bővíté- sét, vagyis a normatív alapú előrelépést jelölik. Ezzel szemben mások elvetik a normatív alapú előrelépés szükségességét, vagyis az eredménytől független jóllét érzetet és elégedettség érzését elegendőnek tekintik ahhoz, hogy a nem formális és informális tanulási aktusok esetében is megvalósuljon az élethosszig tartó tanulás. A szerzők kitérnek az elmúlt évtizedek gazdasági és technológiai változásának hatásaira, azonban az élethosszig tartó tanulás mint társadalmi jelenség történelmi beágyazottságának, a fogalom értelmezésében bekövetkezett változásoknak az áttekintése elmarad, azonban a projekt által képviselt szemlélet értékelését erőteljesen befolyásolhatja és a Delors-jelentés megjelenéseóta történt előrelépéstérzékeltetheti.

$\mathrm{A} z$ élethosszig tartó tanulás koncepciója először a 20. század első felében a nyugati, fejlett társadalmak gazdaságpolitikai stratégiáiban érvényesült, és egy olyan rugalmasabb oktatási rendszer kialakításának igényét eredményezte, mely lehetővé teszi a tanulás fogalmának tágabb értelmezését, valamint a formális oktatáson túli kiterjesztését. Majd az 1990-es években az UNESCO Delors-jelentése (1996) emelte a politikai viták középpontjába, és az élethosszig tartó tanulás koncepció elsősorban válaszként fogalmazódott meg gazdasági és szociális kihívások megoldási javaslataiban, mint például a gazdasági versenyelőny javítása, a globalizáció vagy a növekvő munkanélküliség kezelése. Az élethosszig tartó tanulás koncepciója megjelenésének kezdeti időszakára a nemzeti szintű makroszemlélet volt jellemző. Reformokat kezdeményeztek az oktatáspolitika területén annak érdekében, hogy az oktatás, a tréningek és egyéb képzések rendszere olyan normatívák és eszközök kialakítását tegye lehetővé, melyek az élethosszig tartó tanulás koncepció fennmaradását támogatják. Azonban a tanulás folyamatának eltérő értelmezésére, 
valamint az egyén életében betöltött szerepének és fontosságának tisztázatlanságára hivatkozással számos kritika fogalmazódott meg, amely az élethosszig tartó tanulás koncepciójának tudományos értékét kérdőre vonta, és az ellentmondások feloldását sürgette (Bengsston 2013). A felvetett kritikákat támasztja alá, hogy az élethoszszig tartó tanulás fontosságát hangsúlyozó három meghatározó nemzetközi szervezet a Nemzetközi Munkaügyi Szervezet (ILO), az UNESCO és az Európai Bizottság (EB) eltérő definíciót használ. Az UNESCO a hangsúlyt a tanulási szándékra helyezi, ${ }^{1}$ az ILO az eredményességet tartja fontosnak, ${ }^{2}$ az EB tágabban értelmezi az élethosszig tartó tanulás koncepciót és az ILO álláspontjával egyezően az eredményességre helyezi a hangsúlyt. ${ }^{3}$

Bár a most ismertetett kiadás nem tárgyalja, hogy a NEPS melyik szervezet definícióját követi, és milyen mértékben, a szerzők álláspontja, hogy a NEPS a tanulás folyamatát az eddig megszokottnál szélesebb körben vizsgálja, és a formális, a nem formális, az informális, valamint az életút során megvalósult egyéb képzések és tanulási aktusok minden fajtáját a folyamat részének tekinti. A tanulás aktusát az élet részének és a tanulással járó fejlődést evidenciának veszik a szerzők, a bizonytalanságot kizárólag az eredményes-

1 „[A]z életút során minden tanulási cselekmény, melynek célja a tudás és képzettségek megszerzése, a képességek, kompetenciák bővítése valamely egyéni, szociális, vagy szakmai ok alapján." (UNESCO 1984.)

2 „[A]z életút során minden tanulási cselekmény a kompetenciák és végzettségek megszerzéséért." (ILO 2006.)

3 „[M]inden általános és szakképzési formában, tréningen való részvétel, valamint non formális és informális tanulás, mely az életút során a tudás, a képességek, és a kompetenciák javulásához vezet az egyéni, társadalmi, közösségi, vagy a munkavállalással kapcsolatos tevékenység során, ide sorolandó az iránymutatásra vagy tanácsadásra vonatkozó tevékenységek köre is.” (EB 2006.) ség viszonylatában értelmezik (30. o.). Továbbá kapcsolatot feltételeznek a korai életszakaszban megvalósult tanulási aktusok, a szociokulturális környezet és a későbbi életszakaszokban jelentkező tanulási igény között.

$\mathrm{A} z$ eddig említett nehézségek és kritikai észrevételek mellett fontos megemlíteni, hogy Németország úttörő szerepet játszik a longitudinális kutatások területén. A NEPS mellett jelenleg több egyéb nemzeti panelkutatás is folyik az országban, ilyen például a pairfam, ${ }^{4}$ a $\mathrm{PASS}^{5}$ vagy a NAKO. ${ }^{6} \mathrm{Az}$ összehasonlító országelemzésekre alkalmas nemzetközi panelkutatások száma is növekedett az elmúlt két évtizedben. A nemzetközi gazdasági szervezetek, mint például az OECD vagy az Európai Unió, is használják a panelkutatások adatbázisait ajánlásaik elkészítéséhez. Ezek a nagyléptékü, speciális rendszerü adatbázisok eredményes alátámasztással szolgálnak szociálpolitikai irányvonalak meghatározásához és a nemzeti eltérések elemzéséhez.

A puha tényezők - mint a szociális készségek és a kommunikációs kompetenciák - mára a munkavégzés és a társadalmi szerepvállalás elengedhetetlen részévé váltak. Az átfogó kompetenciavizsgálatok azon kognitív és nem kognitív kompetenciák kialakulásának és szelekciójának egyidejű elemzését teszik lehetővé, melyek az élethosszig tartó tanulás megvalósulásához éppúgy hozzájárulnak, mint a társadalomban való eligazodáshoz és a közösségi kapcsolatrendszer kialakításához. A

\footnotetext{
pairfam - Das Beziehungs- und Familienpanel (angolul: German Family Panel) - https://www. pairfam.de/

5 Panel Arbeitsmarkt und soziale Sicherung (angolul: Panel Study Labour Market and Social Security) - https://www.iab.de/de/ befragungen/iab-haushaltspanel-pass.aspx

6 NAKO Gesundheitsstudie (angolul: German National Cohort - GNC) - https://nako.de/
} 
szerzők álláspontja szerint a NEPS adatbázisa a leíró elemzések mellett a kognitív és nem kognitív kompetenciák kialakulása során létrejövő kauzális viszonyok elemzését is lehetővé teszi. A szerzők hangsúlyozzák, hogy a NEPS óriási előrehaladás a longitudinális kutatások területén és jelentős mérföldkő az élethosszig tartó tanulás szerepének és hatásainak vizsgálatában a németországi társadalmi viszonyok kontextusában. A jelen panelkutatás keretében kialakított adatbázis rendszer felépítését és tartalmát tekintve is az első olyan nemzeti adatforrás, mely longitudinális információt biztosít, méghozzá megőrizve a reprezentativitást a több bemeneti szint összehangolása mellett is. Az adatgyüjtési struktúra, a szerzők szerint, lehetővé teszi az egyéni szintü információgyüjtést a formális oktatásban eltöltött évekről és a kompetenciakészlet alakulásáról. Ezzel párhuzamosan a közvetlen családról, a barátokról és tanulótársakról, családi körülményekről, valamint az oktatási intézményekről, a tréningközpontokról és egyéb kapcsolódó munkahelyekről is folyamatos adatfelvétel történik.

A tanulás szeretete, az ismeretek gyüjtését eredményező motivációk megőrzése elengedhetetlennek bizonyul a technikailag fejlett, gyors változásokat abszolváló társadalmakban való eligazodáshoz és a sikeres egyéni és szakmai életút vezetéséhez. A tanulás szeretetének elsajátítása kedvező esetben már kora gyermekkorban megkezdődik, és megalapozza az egyén tanulás iránti igényét, segíti a motiváció fenntartását, továbbá azon készségek és kompetenciák kialakulását, fejlesztését, melyek támogatják a siker és a sikeres életpálya megélését.

A NEPS új, progresszív aspektusok beépítésével támogatja a tanulási folyamat értelmezési keretének módosulását, bővülését annak érdekében, hogy az oktatási rendszerek és az egyéni tanulási folyamat szakmai és tudományos megítélése fejlődhessen. Továbbá, a nagy adatbázist produkáló panelkutatásokra általában jellemzően, példát mutat arra, hogy a 21. századi információs társadalom törvényi keretein belül hogyan lehetséges az adatgyüjtés és az adatkezelés módjait rugalmas keretek között tartani, az adatgyüjtési felületeket felhasználóbaráttá tenni, és mindemellett az adattárolás biztonságát és az adatvédelem szabályait betartani.

A NEPS és hasonló empirikus kutatások hatalmas adatbázisa nemcsak a szakmai és tudományos közösség munkáját támogathatja, de alátámasztást adhat a szociálpolitika aktuális kihívásainak kezelésére még akkor is, ha a javaslatok alkalmanként kizárólag nemzeti szinten értelmezhetők. A szerzők által végzett elemző munka és az adatfelvételek rendszeres felülvizsgálata pedig támogatja $a z$ adatbázisban való eligazodást, és további tervezett kutatásokhoz kapcsolódási pontokkal szolgál.

\section{IRODALOM}

Bengsston, J. (2013) National Strategies for Implementing Lifelong Learning (LLL) - The Gap between Policy and Reality: An International Perspective. International Review of Education, Vol. 59. No. 3. pp. 343-352. https://doi.org/10.1007/s11159-013-9362-4

Delors, J. (1996) Learning: The Treasure within. Report to UNESCO of the International Commission on Education for the Twenty-first Century. Paris, UNESCO Publishing. 
Sturgis, P., Allum, N. \& Brunton-Smith, I. (2009) Attitudes over time: The psychology of panel conditioning. In: P. Lynn (ed.) Methodology of longitudinal surveys. Chichester, John Wiley \& Sons. pp. 113-126.

United Nations (2015) Transforming our World: The 2030 Agenda for Sustainable Development. https://sustainabledevelopment.un.org/content/documents/21252030\%20Agenda \%20for\%20Sustainable\%20Development\%20web.pdf

A cikk a Creative Commons Attribution 4.0 International License (https://creativecommons.org/licenses/ by/4.0/) feltételei szerint publikált Open Access közlemény, melynek szellemében a cikk bármilyen médiumban szabadon felhasználható, megosztható és újraközölhető, feltéve, hogy az eredeti szerző és a közlés helye, illetve a CC License linkje és az esetlegesen végrehajtott módosítások feltüntetésre kerülnek. (SID_1) 